LEARNING TO FORGET 



\section{LEARNING TO FORGET}

Schooling and

Family Life in

New Haven's

Working Class,

I870-I940

Stephen Lassonde

Yale University Press

New Haven and London 
Published with the assistance of the Frederick W. Hilles Publications Fund of Yale University.

Copyright (C) 2005 by Yale University.

All rights reserved.

This book may not be reproduced, in whole or in part, including illustrations, in any form (beyond that copying permitted by Sections 107 and 108 of the U.S. Copyright Law and except by reviewers for the public press), without written permission from the publishers.

Set in Galliard type by Achorn Graphic Services.

Printed in the United States of America by Sheridan Books, Ann Arbor, Michigan.

ISBN 0-300-07396-8

Library of Congress Control Number: 2004117580

A catalogue record for this book is available from the British $\mathrm{Li}$ brary.

The paper in this book meets the guidelines for permanence and durability of the Committee on Production Guidelines for Book Longevity of the Council on Library Resources.

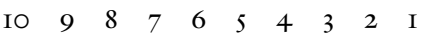


TO MY PARENTS, PAT AND MERT LASSONDE, AND TO MY CHILDREN, ALEX AND JONATHAN LASSONDE 
